\title{
CONCEPTIONS OF NURSING STUDENTS ON HEALTH PROMOTION RELATED TO PSYCHOACTIVE SUBSTANCES
}

\author{
María Delia Rojo ${ }^{1}$ \\ Sonia Maria Villela Bueno ${ }^{2}$ \\ Edilaine Cristina da Silva ${ }^{3}$
}

Rojo MD, Bueno SMV, Silva EC. Conceptions of nursing students on health promotion related to psychoactive substances. Rev Latino-am Enfermagem 2008 maio-junho; 16(especial):627-33.

This qualitative study aimed to investigate the perception of undergraduate nursing students on health promotion in view of the use of psychoactive substances. Nine undergraduate students, attending the last disciplines of the first semester, participated in the study and were divided in two focal groups. The theoreticalmethodological referential was based on Paulo Freire's theory of conscientization. Data were processed through content analysis, demonstrating that students find difficulties in planning intervention strategies in health promotion in view of the drug phenomenon, because the knowledge provided by the university has a biologist tendency, typical of the medical model, recognizing a gap between theory and practice. Nevertheless, they manage to reconstruct their knowledge and become aware of their role as future health promoters in the face of drug use and abuse.

DESCRIPTORS: health promotion; nursing students; substance-related disorders

\section{CONCEPCIÓN DE LOS ESTUDIANTES DE ENFERMERÍA SOBRE PROMOCIÓN DE LA SALUD ANTE EL USO DE SUSTANCIAS PSICOACTIVAS}

Este estudio de modalidad cualitativa tuvo como finalidad indagar acerca de la concepción que los estudiantes de enfermería de la universidad poseen sobre la promoción de la salud, ante el uso de sustancias psicoactivas. Participaron nueve estudiantes, cursando las últimas asignaturas del primer ciclo de la carrera, reunidos en dos grupos focales. El referencial teórico-metodológico se fundamentó en la Teoría de la Concientización de Paulo Freire. Los datos fueron interpretados mediante el análisis de contenido, evidenciándose que los estudiantes encuentran dificultades al planificar estrategias de intervención en promoción de la salud ante el fenómeno de las drogas, debido a que los conocimientos brindados en la universidad poseen una tendencia biologista, propia del modelo médico, reconociendo a su vez una desarticulación entre la teoría y la práctica. A pesar de ello, logran reconstruir sus conocimientos y tomar conciencia de su rol como futuros promotores de salud ante el uso y abuso de drogas.

DESCRIPTORES: promoción de la salud; estudiantes de enfermería; trastornos relacionados con sustancias

\section{CONCEPÇÃO DOS ESTUDANTES DE ENFERMAGEM SOBRE PROMOÇÃO DA SAÚDE RELACIONADA AO USO DE SUBSTÂNCIAS PSICOATIVAS}

Este estudo qualitativo objetivou indagar a respeito da concepção dos estudantes de graduação em enfermagem sobre a promoção da saúde, frente ao uso de substâncias psicoativas. Nove estudantes, cursando as últimas matérias do primeiro ciclo da carreira, participaram do estudo e foram reunidos em dois grupos focais. O referencial teórico metodológico se fundamentou na Teoria da Conscientização de Paulo Freire. Os dados foram interpretados mediante a análise de conteúdo, evidenciando-se que os estudantes encontram dificuldades no planejamento de estratégias de intervenção na promoção da saúde frente ao fenômeno das drogas, pois os conhecimentos adquiridos na universidade possuem uma tendência biologista, própria do modelo médico, reconhecendo-se assim uma desarticulação entre a teoria e a prática. Apesar disso, conseguem reconstruir seus conhecimentos e tomar consciência de seu papel como futuros promotores da saúde diante do uso e abuso de drogas.

DESCRITORES: promoção da saúde; estudantes de enfermagem; transtornos relacionados ao uso de substâncias

${ }^{1}$ Teaching Diploma in Nursing, M.Sc. in Health Systems and Social Security, Faculty, Córdoba National University, Medical Sciences School, School of Nursing, Argentina, e-mail: jazni@arnet.com.ar; ${ }^{2}$ PhD in Education, Faculty, e-mail: smvbueno@eerp.usp.br; ${ }^{3}$ RN, Ph.D. in Nursing, Faculty, e-mail: nane@eerp.usp.br. University of Sao Paulo at Ribeirão Preto, College of Nursing, WHO Collaborating Centre for Nursing Research Development, Brazil 


\section{INTRODUCTION}

The drug phenomenon has become a worldwide social problem, particularly in Latin American countries. Constantly increasing and complex, this phenomenon is notably impacting the health of communities.

One of the most appropriate methodologies to visualize and understand this phenomenon is the holistic paradigm in international healthcare. It allows for the clear identification of several factors that play a role and the population health status, particularly in Latin America countries. It also implements actions focused on health promotion and the prevention of drug use and abuse ${ }^{(1)}$.

The consumption of psychoactive substances follows the human species since its origins and evolution. Nowadays, data referring to the prevalence of drug consumption in our society display frequent variations, produced by increased consumption of both cocaine chlorhydrate and marihuana in young population groups. This situation indicates a progressive tendency in the magnitude and damages to society, caused by indiscriminate use of psychoactive substances. In this context, Nursing professionals are essential agents in the process of social transformation in countries that participate in health promotion and drug reduction programs ${ }^{(2)}$.

In Argentina, $40 \%$ of young people between 12 and 15 years old have already consumed alcohol and tobacco, while the consumption of illicit drugs includes, in decreasing order: marihuana, cocaine chlorhydrate, tranquilizers, inhalants and solvents. Gender differences tend to be insignificant ${ }^{(3)}$. Drug use has become universal, relating to subjects and sociocultural contexts that negatively influence people's daily life ${ }^{(4)}$.

For the last decades in Argentina, the perception of drug problems have been part of the collective imaginary, to the extent that psychoactive substances occupy an increasingly preponderant place in matters that have been influencing the evolution of societies. However, reality has changed objectively, as well as perceptions in societies. The consumption standards have varied with the arrival of new substances in our context. Everyday life has clarified the view of problems and performances, and several responses have been used, depending on the view and social conception regarding drug use and consumption.
In this context, it is convenient to stress the importance of academic education in Nursing, where the student acquires knowledge that can be applied to professional practice and, in general, to healthcare offered to the community. Nursing, as a career, can participate by creating social support, reinforcing community health and improving together with other health professionals, in order to offer proper health promotion, prevention and education.

The evaluation of beliefs and values involved in care delivery is fundamental, as well as the evaluation of professional healthcare practice ${ }^{(5)}$. According to this way of thinking, it is essential to determine the best way to respond to the innumerable changes and global tendencies that are critically affecting community health and welfare. Moreover, strategies concerning health promotion need to be developed, dealing with the inequalities and facing the new millennium demands in a pertinent way.

There is great profusion and diversity of information regarding the problem. However, not enough studies deal with psychosocial aspects, refer to knowledge about the drug phenomenon from an interpretative-social focus, and adopt the description of Nursing students' conceptions about health promotion, in view of the use of psychoactive substances, as their central axis.

\section{METHODOLOGY}

This research has exploratory-descriptive characteristics, in line with the logic of qualitative methodology, with the orientation towards problemsolving as one of the basic pillars. The goal is to get to know college students' critical and reflexive learning.

An exploratory approach is used, identifying how the research participants construct the consumption of psychoactive substances and health promotion and searching for the meanings in their statements and manifestations, in order to better understand their conceptions. To achieve those objectives, a discovery context was used, analyzing the processes in their complexity and addressing contextualized experiences, with the presence of the social reality in the interaction among members.

In an attempt to understand the reality, questions or assumptions were described as people interacted with them: "it is important that the 
researcher finds sense and meaning in the data provided by the social subjects and the context" ${ }^{\prime(6)}$.

The methodological theoretical focus of the study is based on Paulo Freire's Educational Theory, which was considered appropriate to respond to the students' need to think about their own practices. Likewise, its approach was considered to stimulate the students' subjectivity, since they are subjects that treat, discuss, decide and operate according to the knowledge acquired in college.

The sample was intentional, consisting of two groups: one group of five students and another of seven, respectively. These students were attending the last subjects in of the first semester of the Nursing course and were part of two focus groups. The first group comprised undergraduate students who did not have any work experience, and the second included undergraduate students who had been working or had already developed activities in the Nursing area.

Focus group interviews and non-participant observation were used for data collection. The group sessions facilitated the expression of the participants' perceptions, beliefs, values and social conceptions about health promotion and dependence on drugs. These interviews were recorded for later transcription, effective when asking for information about perspectives and experienced events.

The observation was focused on capturing the object's complexity, finding out about the actual context and what the students perceive and feel, as well as the interrelations among members of the groups under analysis. This permitted questioning the processes the students perform when demonstrating their knowledge on health promotion and drugs consumption, from a problem-solving perspective.

The application of the previously described techniques allowed for the exploration of the members' actions regarding their attitudes, care models and healthcare needs of the community, offering a space that allowed them to freely express themselves about the knowledge acquired at university. Content analysis $^{(7)}$ was used for data reading and description, which made it possible to achieve the study purpose, since it was based on a group of analysis and communication techniques.

The material obtained from both group interviews and observation records was then explored and organized. During the entire methodological process, there was a continuous and sequential analysis of the episodes, which enabled and facilitated their interpretation.

\section{RESULTS AND DISCUSSION}

Three analysis categories could be extracted from the focus group participants' statements.

Nursing and Health Promotion. Application to future professional practice

The members from both focus groups were situated in the new radical model, which responds to the premises of health promotion and education. This model focuses its orientation on the enlargement of people's critical awareness, including four specific actions: thinking about personal realities, stimulating the search for and collective identification of the causes and manifestations of this reality, examining its implications and developing actions aimed at changing it.

In this context, the subjects consider that promotion has to be done by everyone, by supporting actions aimed at the community and working in groups. The mentioned model maintains that, instead of working with isolated individuals, it should be done in groups, since the group environment facilitates the increase of critical awareness through its potential to promote exchanges of ideas among subjects.

It is necessary to know the needs of the population. It is necessary to perform fieldwork and be able to see the reality, talk to people and listen to them. The dialog created in this context determines the collective awareness of the people's living conditions. However, it also allows for the acknowledgement that, behind the decisions of the individuals, there is a complex combination of factors and elements that influence and would influence them, so that previously acclaimed empowerment would not be possible.

Students attribute great importance to health promotion in the context of psychoactive substance use according to social classes, when maintaining that poverty is a factor that predisposes the subject to the consumption of such substances, as it allows them to evade their reality. Likewise, both groups agree that promotion campaigns against drug use are not useful, since most of them emphasize negative consequences, expressing: It is not positive to prohibit. They also mention that, when coming across subjects at risk of consuming psychoactive substances, they need to take actions 
to help them, since, by themselves, these subjects could not avoid the use and abuse of those substances.

The subjects mention the difficulty they face to plan health promotion actions in Nursing care, since the medical models of health care, cure and rehabilitation predominate in their practice. They express that, at the university, although they receive significant content along the first semester of the course, they are generally taught to follow a biologistic orientation, and only some of it refers to health promotion in view of psychoactive substance use.

They say they face obstacles to express the exact meaning of health promotion. Those obstacles, thus, prevent them from thinking of interventions they would perform in the community, alleging a lack of practical experience.

Praxis $^{(8)}$ is highlighted as a privileged place for nurses to apply health promotion strategies against the drug phenomenon. Then, the development of health education activities can be proposed, considered in some budgets, incorporating the recognition of dignity and integrity of the subjects involved in the educational process, including awareness and freedom.

Generally, vertical focus, in-class learning and a biomedical health concept have preponderated in most healthcare education trends. In the opposite sense, Paulo Freire, in his popular education, says that participative methods activate people's confidence and free determination. These methods are popular nowadays, as their application is observed in the fields of healthcare education and communication.

The drugs phenomenon: opinions and beliefs on the use of psychoactive substances

The compiled data, as expressed by the students, reveal the relative importance they attach to the phenomenon. At first, they may not see it as a problem situation, which they can face through intervention actions or strategies in the community.

Lately, the negative consequences of drugs consumption have become more evident as they come up in the health and social sectors. These include both social connotations of drug dependence, marginality characteristics, illegality, marginalization; and infections and diseases associated to intravenous consumption $^{(9)}$.

The initial age for illicit and licit drug use in Argentina is between 8 and 12 years old. Statistics indicate that the consumption of inhalants starts at an early age. These data have significantly changed lately, since children at early ages start using all kinds of drugs they can reach, thus responding to the social class they belong to. Moreover, a striking tendency towards multiple consumption of toxic substances is evident, in which alcohol and psychoactive drugs stand out, among others. Both groups give major importance to age, concerning adolescence, and mention that health promotion should start with this vulnerable age group.

Regarding the current situation of the phenomenon in Argentina, students admit they do not know of any data concerning the existence of laws addressing drugs in the country, but they state that Argentineans are used to breaking laws, to not complying with them. They manifest that drugs have become a kind of business that makes the world go round and that, if there are laws, they favor the distributors, because there is money involved. Thus, they ignore whether the State would be willing to perform actions to really face the problem.

The members of the groups incorporated data referring to explanatory models of drug use and to the image they have of substance users into their expressions. Thus, they maintain the moral model, expressing that they can see the user as a sick person, a thief, agreeing with the statement that the consumption of certain drugs harms individuals and society, which is why the user should be punished.

Students from the group that does not work say: we can see consumer subjects as 'drug addicts' who do not look for solutions. That is why we make them guilty, although it is also possible to see them as sick people, who have a problem that is difficult to cure. The group that works briefly refers to the cultural model, emphasizing self-esteem and the importance of what the family and the school teach.

These models characterize addiction to these substances as a progressive and incurable disorder with genetic-biological origins. Besides, when associated to individual development difficulties, they cause susceptibility and dependence ${ }^{(10-11)}$.

In another sense, content on the drug phenomenon has recently been incorporated into the undergraduate curriculum of Nursing schools. That happened because it was considered essential for critical Nursing education, with the purpose of offering appropriate care to the community.

Nevertheless, a lack of knowledge regarding drug dependence is observed among the members from both focus groups, since part of their opinions is 
superficial and permeated with intuitive knowledge. As such, it can be inferred that either the curricular content mentioned has been approached superficially or that undergraduate students did not grant much importance to it and did not perform autonomous learning, complicating not only their visualization of the phenomenon as a social problem, but also preventing them from being creative in answering questions about what strategies they would plan for health promotion, prevention and education to deal with this phenomenon.

A critical look at the students' reality. The acquisition of significant knowledge at the university

Education on the drugs phenomenon education should be included in coherence with other aspects of people's lives, so as to integrate it into health promotion activities. Health promotion is not simply considered an information process, since it does not lead to behavior modifications. These activities should take into account the need to promote behaviors aimed at overcoming the motivation to have contact with drugs ${ }^{(9)}$.

In this context, the university is considered a social institution, responsible for human resource development at a high academic level. Consequently, it should educate and prepare professionals to face the increasing challenges successfully, whether in the scientific, technical or cultural field ${ }^{(11)}$.

Regarding the latter, the members of the groups express that the students have broad initiatives at their disposal to intervene in how some content related to practice is approached at the university but, later on, they cannot continue applying the same initiatives. In spite of the content offered, we do not have health promotion in view of drug dependence - only to treat the consumer, which depends on the attitudes of different professors.

It is worth mentioning the importance of content integration in the curricular project, in two directions: on the one hand vertical integration, connecting contents from the same discipline; on the other hand horizontal integration, which implies significant relations among the curricular contents of different disciplines ${ }^{(12)}$.

Members who already had work experience in the area consider the importance of learning and working on health promotion and drug dependence in an interdisciplinary way. They support that Nursing, as a single subject, can treat the problem partially.
Due to the complexity of drug abuse and its multiple causal factors, the possibility of getting a complete view of the phenomenon reveals to be an illusion.

Consequently, it generates the need to approach several disciplines that try, just like Nursing, to understand man in order to set a benchmark for interdisciplinary and intersectorial work. However, as interdisciplinarity advances, new challenges appear. Science areas do not communicate often and are often resistant to communication, jeopardizing innovation $^{(13)}$.

Gathering information on knowledge construction is the key to understand the process performed, since the knowledge owned by students is an indicator of the articulations between thought and action. Nowadays, social-historical and cultural constructivism is privileged as a pedagogical perspective, in which the intersubjective relation stands out as the fundamental base for learning. From interaction, the recognition of knowledge and life experiences, the overcoming critical theory reappears: the awareness pedagogy.

Likewise, students know what is happening nowadays in a superficial way. They do not have much data regarding the reality around them, and are not interested in acquiring knowledge on the theme through autonomous and independent learning. As Paulo Freire said, they cannot move from the naïve curiosity to epistemological curiosity.

Professional education is considered as a process in which the subject undergoes different experiences and interacts with several knowledge bodies and foci, embracing both the periods of formal and systematic preparation and professional practice $^{(14)}$. Both focus groups say We have some knowledge, but we miss the practice.

Regarding the theory-practice link, this study focused on the first years of practical experience and the educative value it offers. The student is introduced to the culture of the institution at the same time as action outlines are incorporated. In this context, it imposes the idea of reflecting on current practices, turning this into a conscious and autonomous process, in which a narrow relation among intentions, reality and the relations between base and action theories can exist.

In the presentation of practice, from an interpretative and critical perspective, there is an attempt to overcome limitations by incorporating 
notions of understanding, interpretation, meaning and action. Thus, theory is built in articulation with practice $^{(15)}$.

Students expose uncertainties about the space they may and should occupy as future health promoters, as well as about when and how to participate, which strengthens this problem due to the lack of confidence generated by their inexperience. Thus, a pedagogical transformation is needed, in which relations, functions and roles of the educators and students are changed, introducing a participative methodology and creating conditions that allow for the development of creativity and research capacity.

The ever-changing needs, nature and level of substance abuse require that nurses be ready to work with people whose problems are related to alcohol and drug abuse. Nursing performance is an essential resource in care delivery to subjects, families and communities. Besides, in order to be able to perform their activities, nursing professionals should have clinical, cognitive and relational abilities ${ }^{(16)}$.

When synthesizing the group meetings that were held, the students managed to evaluate the context, reality and resources at their disposal. This evaluation contributes by offering approach and solution strategies, trying to recover the learning in the reconstruction of professional knowledge.

Society and culture demand reflection on health problems as part of a complex social configuration. If health promotion and prevention permit the visualization of the subject's life process in everyday dynamics, indicating lifestyle transformations and the process of thinking about one's own fears and judgments, different conflicting situations can be addressed.

\section{FINAL CONSIDERATIONS}

In summary, the students' conceptions on health promotion, in their own social-cultural context, containing characteristics of the world around them, determined the meaning they grant to the use of psychoactive substances, as well as the possibilities to apply their knowledge in their future professional practice. These thoughts consider questions related to the role of the articulation between theory and practice in the development of students' experiences.
Professional practice appears as a defining element in the incorporation of significant problems that affect professional exercise. That kind of representation regarding practice implies acknowledging the validity of certain identifying traits of the profession, enclosed in the historical conditions they are manifested in within a certain society.

The inclusion, hiding or explanation of these practices and the way they are allocated by the disciplines and learning promoted are matters related to the presentation of content and define an interesting field for reflecting about the curricular structure of the career.

The students highlight the importance of interdisciplinarity to address those themes. Interdisciplinarity is feasible whenever there is a world view with points in common, a certain similarity of intentions, shared values, perspectives to move beyond rigid and bureaucratic academic structures, as well as the conviction that sharing a task is much richer than doing it alone.

This study focused on a problem-solving benchmark, in which the students managed to articulate the theme they talked about with arguments and thoughts, evidencing their knowledge construction processes and including themselves as future health promoters in this scenario, by discovering that they possessed previous knowledge that could be recovered.

Health professionals are able to generate cognitive and metacognitive competences, capture knowledge that is socially valid and reproduce it in their work context. According to Paulo Freire, it should be asked: Why do we not talk to students about the concrete reality they should associate the content that is taught to? Why do we not establish links between the students' fundamental curricular knowledge and their social experience as individuals? ${ }^{(17)}$.

\section{ACKNOWLEDGEMENTS}

Acknowledgements to the Inter-American Drug Abuse Control Commission/CICAD of the SubSecretary of Multidimensional Security at the Organization of American States/OAS, the Brazilian Anti-Drugs Secretary/SENAD, faculty members at the 
University of São Paulo at Ribeirão Preto College of Nursing, WHO Collaborating Centre for Nursing Research Development, Brazil, to the population who participated in the studies and to the representatives from eight Latin-American countries who participated in the I and II On-Line Specialization Program for Research Capacity-Building on the Drugs Phenomenon-PREINVEST, offered in 2005/2006 by the University of São Paulo at Ribeirão Preto College of Nursing, as a distance education course.

\section{REFERENCES}

1. Wright MG, Chisman A. A Saúde Internacional, o Fenômeno das Drogas e a profissão de Enfermagem na América Latina. Texto \& contexto enferm 2002 abril/junho; 13(2):264.

2. Gelbcke F, Souza Padilla MI. O fenômeno das drogas no contexto da promoção da saúde. Texto \& contexto enferm $2002 \mathrm{abril} /$ junho 2002; 13(2):273-8.

3. Secretaría de Programación para la Prevención de la Drogadicción y la Lucha contra el Narcotráfico. Informe sobre drogas. Presidencia de la Nación. República Argentina; 2000. 4. Romaní O. Las Drogas: Sueños y Razones. 2. ed. Barcelona: Ariel; 2004.

5. Escuela de Enfermería de Ribeirão Preto. Organización de los Estados Americanos. [página en línea]. Ribeirão Preto: EERP; 2005. [acceso en junio 2007]. Pillón SC. Epidemiología del Uso de Drogas. Programa de Especialización On-Line de Capacitación en Investigación de las Drogas. [1 página]. 2005. Disponible en: http://preinvest.cicad.oas.org/ modulo\%20II.asp.

6. Taylor S, Bogdan R. Introducción a los Métodos Cualitativos de Investigación. Barcelona: Paidós; 1984.

7. Bardin L. Análise de Conteúdo. Lisboa: Editora 70; 2004.

8. Freire P. Pedagogía del Oprimido. Buenos Aires: Argentina Editores; 1972.

9. Inchaurraga S. Drogodependencias: reflexiones sobre el sujeto y la cultura. Argentina: HomoSapiens; 1998.

10. Kornblit AL. Nuevos estudios sobre drogadicción: consumo e identidad. Buenos Aires: Biblos; 2004.

11. Lindo AP. Universidad, conocimiento y reconstrucción nacional. Buenos Aires: Biblos; 2003.

12. Iniesta TS. Organizar los contenidos para ayudar a aprender. Argentina: Magisterio Del Río De La Plata; 1999.

13. Demo P. Conhecer e aprender: sabedoria dos limites e desafios. Porto Alegre: Armet; 2001.

14. Felman D. Ayudar a enseñar: relaciones entre didáctica y enseñanza. Argentina: Aique; 2004.

15. Sanjurjo L. La formación práctica de los docentes: reflexión y acción en el aula. Argentina: HomoSapiens; 2002.

16. Pillón SC, Luis MV, Laranjeira R. Nurses training on dealing with alcohol and drugs abuse: a question of necessity. Rev Hosp Clin. Fac Med 2003; 58:119-24.

17. Freire P. Pedagogía de la Autonomía. Argentina: Siglo XXI；2002. 